\title{
ANALYSIS ON THE STRENGTH CHARECTERISTICS OF CLAYEY SOIL WITH GEOPOLYMER ENZYME (BIOCHEMICAL ENZYME)
}

\author{
S. Janaki Raman*, P. D. Arumairaj, R. Tikson Sebastian, J. Jerushan, \\ D. Jebaraj Samuel Dorai and Nathaniel Joseph Thomos \\ Department of Civil Engineering. KITS, Coimbatore \\ "E-mail: janakiraman@karunya.edu
}

\begin{abstract}
A large part of India is covered with Black Cotton soil which is clayey in nature. These are the soils of residual deposits formed from basalt. In this research, bio-enzymes a chemical plasticizer and their effect on the engineering properties of soil are discussed. Recently there are many bio-enzymes are available for soil stabilization. Here we used biochemical enzyme-ECOZYME AE-40 in soil stabilization. The black cotton soil sample was collected from Kovilpatti, Tamil Nadu. The soil samples are treated \& tested in the laboratory. The results of consistency limit, unconfined compression test, free swell index, Proctor compaction test CBR test indicates the properties of soil, which are important for the pavement construction. In this CBR test value is considered while designing flexible pavement. The treated and untreated soil condition is should vary among laboratory investigation in flexible pavement design (IRC: 37-1970)

Keywords: Residual deposits, Bio-enzymes, Terazyme, Ecozyme, Consistency limits, chemical concentration

(C) RASĀYAN. All rights reserved
\end{abstract}

\section{INTRODUCTION}

Bio-enzyme is natural, non-toxic, non-flammable, non-corrosive liquid enzyme formulation fermented from vegetable, fruit and sugarcane extracts that improve the engineering qualities of soil, facilitates higher soil compaction densities and increases stability. A bio-enzyme called Ecozyme is used to stabilize the expansive soil. Enzymes catalyze the reactions between the clay and the organic cations and induce the cat-ionic exchange process to reduce adsorbed layer thickness. The chemical stabilization must be performed by mixing the chemical thoroughly with the soil which is very difficult, but bio-enzyme is easy to use as it can be mixed with water as it is soluble in water it can be sprinkled over the soil and compacted.

\section{EXPERIMENTAL}

\section{Characteristics of Black Cotton Soil Under Various Enzymes}

Vast areas of India consist of Black Cotton Soil which is rich in clay content, low strength and minimum bearing capacity. The engineering performance of such soil is also poor that makes the engineers work on the cost-effective and eco-friendly methods for improving the engineering properties of poor soils. It has been found that Terrazyme treated Black Cotton soil shows a significant increase in Unconfined Compressive strength with longer curing period. Bergmann (2000) concluded through studies that BioEnzymes need some clay content to strengthen the soils. It was observed that at least $2 \%$ clay is needed for successful stabilization whereas 10 to $15 \%$ clay gave very good results ${ }^{1}$. The product formed after the application of TerraZyme is biodegradable in nature and the effect is permanent. Also, it eliminates the use of granular subbase and subgradecourse in the pavement construction ${ }^{2}$. Unconfined Compressive Strength of both black cotton soil and red soil showed tremendous improvement with drying and curing in a laboratory desiccators after treating it with TerraZyme. The properties of Black cotton soil have been much improved by stabilizing with a TerraZyme dosage of $200 \mathrm{ml} / 2.0 \mathrm{~m} 3$ of soil and for red soil by

Rasayan J. Chem., 11(4), 1729-1733(2018)

http://dx.doi.org/10.31788/RJC.2018.1143089

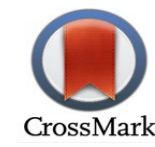


RASĀYAN J. Chem.

Vol. 11 | No. 4 |1729 - 1733| October - December | 2018

$200 \mathrm{ml} / 3.0 \mathrm{~m} 3$ of soil. Hence this dosage is considered as the optimum one ${ }^{3}$. Soaked CBR and Unconfined Compressive Strength of soil treated with bio-enzyme have shown a greater increase than that of soil reinforced with geotextile. $200 \mathrm{ml} / 2 \mathrm{~m} 3$ is the optimum dosage of Terrazyme. Strength characteristics have greatly improved at this dosage. CBR and Unconfined Compressive Strength have increased with increase in the curing period. The optimum position of coir geotextile is $7.5 \mathrm{~cm}$ from the top of the mould. Pavement thickness can be reduced if the subgrade soil is treated with bio-enzyme. Stabilization of subgrade with bio-enzyme offers a durable and aggregate-free pavement. Microstructure analysis shows that treatment of soil with Terrazyme results in a reduction of voids in the soil structure with a closer orientation of soil particles ${ }^{4}$. These compounds are very important in the medicinal and pharmaceutical fields because of their wide spectrum of biological activities. Most of them show biological activities such as antibacterial, antifungal as well as antitumor activity. Transition metal complexes derived from the Schiff base ligands with biological activity have been widely studied. This review summarizes the synthesis and biological activities of Schiff bases and its complexes ${ }^{5}$.A notable amount of improvement can be seen in the moisture content and maximum dry density in the soil treated with Copper Slag and GGBS. Cost wise, admixtures (less costly) reduces the amount of copper slag and GGBS ${ }^{6}$. The adsorption isotherm of the $\mathrm{Cu}$ (II) adsorbed onto the composites followed both Langmuir and Freundlich isotherm; however, it was dominantly to Langmuir model. The adsorbent adsorption capacity at the best condition against $\mathrm{Cu}$ (II) metal ion in metal craft waste was $17.38 \mathrm{mg} / \mathrm{g}$ which it was smaller compared with the model solution that is $22.19 \mathrm{mg} / \mathrm{g}^{7}$.

In this study, the strength of the Untreated black cotton soil and Enzymatic soil (Ecozyme + black cotton soil) to be tested after the curing period of Odays, 7days, 14days, 21days and 28days for various Ecozyme dosages $200 \mathrm{ml} / 3 \mathrm{~m}^{3}, 200 \mathrm{ml} / 2.5 \mathrm{~m}^{3}, 200 \mathrm{ml} / 2 \mathrm{~m}^{3}, 200 \mathrm{ml} / 1.5 \mathrm{~m}^{3}$ :

1. To conduct various tests such as Preliminary test, Compaction test, Unconfined Compression Test (UCC), Soaked and Unsoaked California Bearing Ratio (CBR) test for untreated soil and enzymatic soil.

2. To improve the strength of the black cotton soil up to great extent, which signifies the bearing capacity and the resistance to deformation increased in the stabilized soil.

\section{Analysis Methodology}

\section{RESULTS AND DISCUSSION}

Eco-zyme is a non-toxic material that is manufactured through a natural fermentation process by using sugar and vegetables. It is also blended with a biodegradable surfactant that decreases the surface tension, bringing the enzymes in closer contact with the soil particles, and accelerates enzymatic reactions. When mixed with water and applied during compaction, eco-zyme acts upon the soil's organic fines through a catalytic bonding process producing like a cementing agent. The result is a durable and water-resistant mix that can be used in any climatic conditions as a sub-grade or as primary surfacecoarseie: natural or organic compounds.

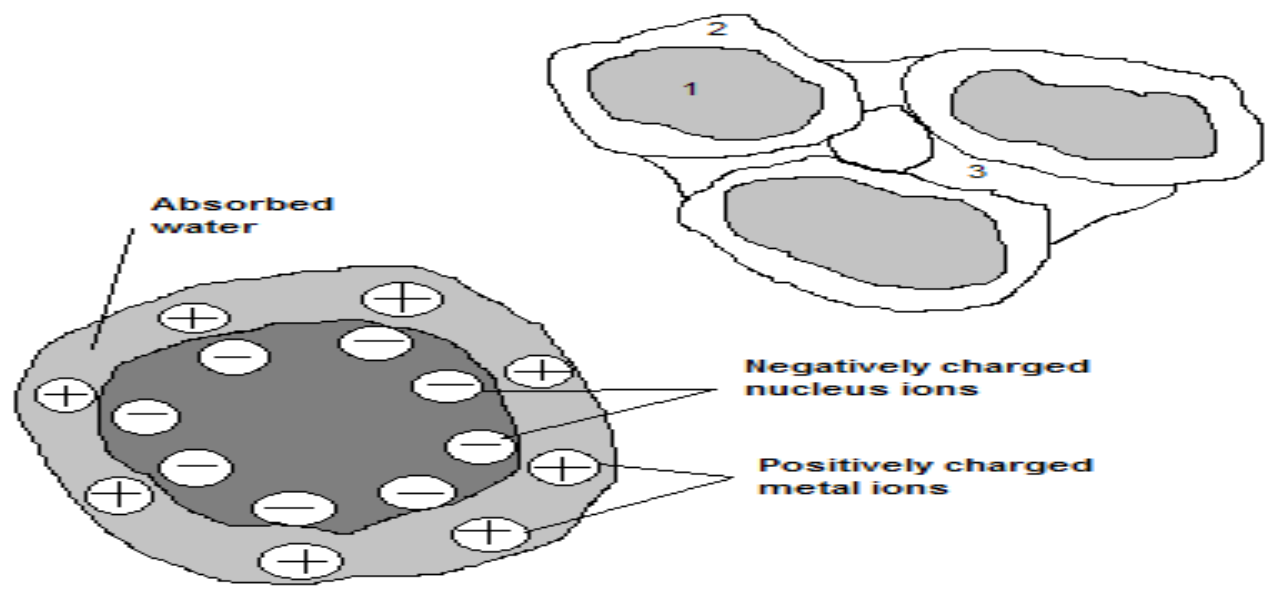

Fig.-1: Molecular Behavior of Clayey of Soil 
Table-1: Properties of Enzyme

\begin{tabular}{c|c|c}
\hline S. No. & Properties & Values \\
\hline 1 & Boiling point & $212^{\circ} \mathrm{F}$ \\
\hline 2 & Specific Gravity & $1.04-1.06$ \\
\hline 3 & Evaporation rate & Same as $\mathrm{H}_{2} \mathrm{O}$ \\
\hline 4 & Solubility & $100 \%$ \\
\hline 5 & Appearance /Odor & Brown color odorless \\
\hline 6 & $\mathrm{pH}$ & Neutral \\
\hline
\end{tabular}

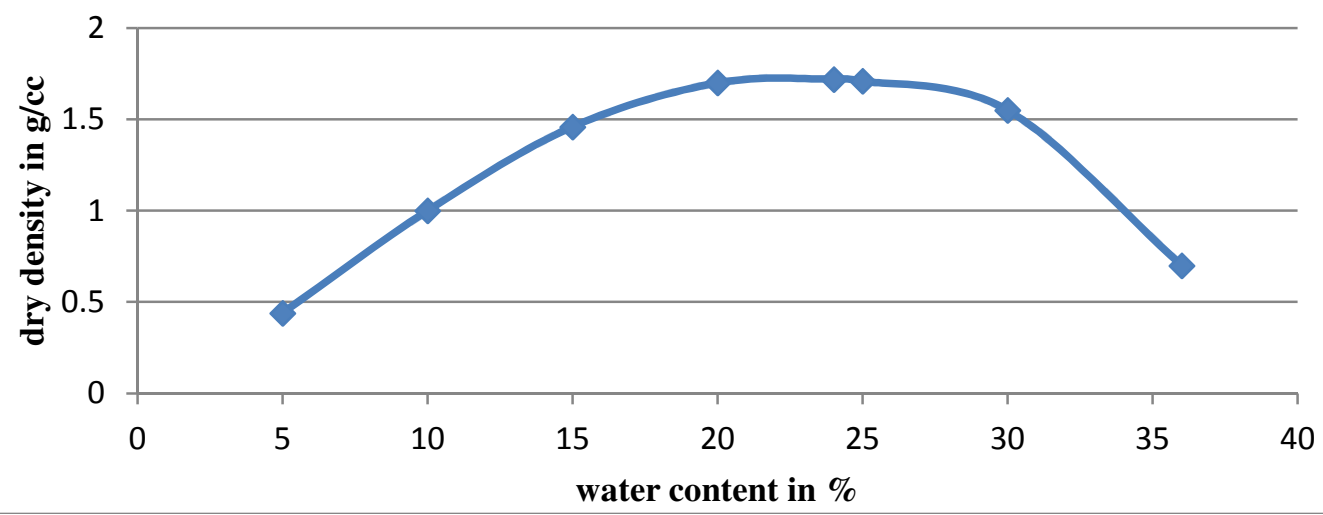

Fig.-2: Optimum Moisture Content of Soil

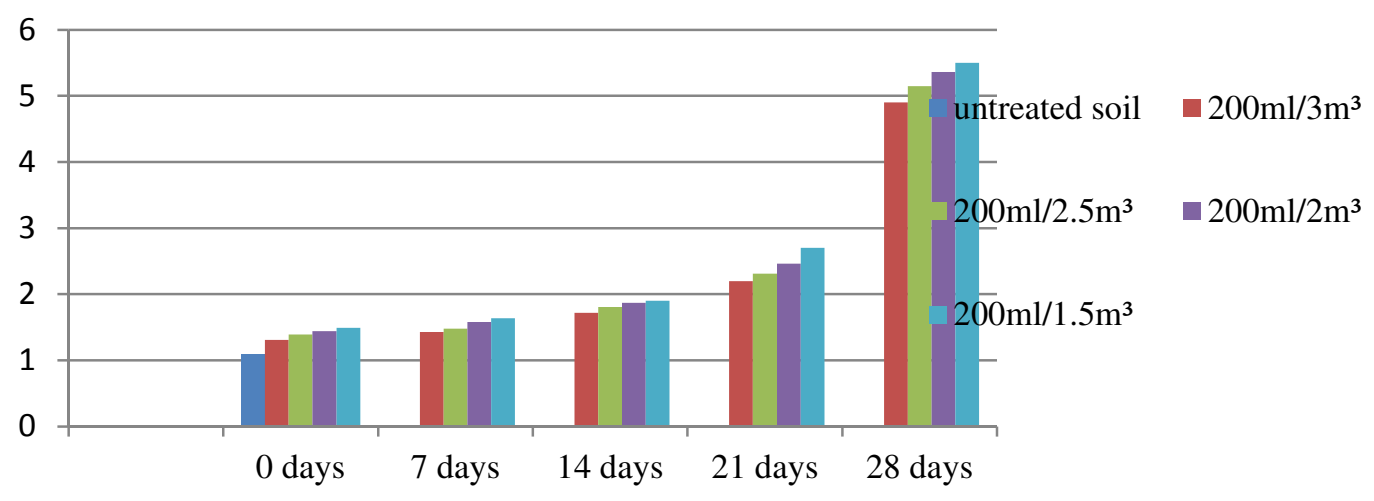

Fig.-3: Soaked CBR Value of Enzymatic Soil.

Table-2: Soaked CBR Value of Enzymatic Soil.

\begin{tabular}{|c|c|c|c|c|c|}
\hline \multirow[t]{2}{*}{ Soil Enzyme Dosage } & \multicolumn{5}{|c|}{ Curing Period } \\
\hline & 0 Day & 7 Days & 14 Days & 21 Days & 28 Days \\
\hline Untreated soil & \multicolumn{5}{|l|}{1.1} \\
\hline $200 \mathrm{ml} / 3 \mathrm{~m}^{3}$ & 1.31 & 1.43 & 1.72 & 2.2 & 4.9 \\
\hline $200 \mathrm{ml} / 2.5 \mathrm{~m}^{3}$ & 1.39 & 1.48 & 1.81 & 2.31 & 5.15 \\
\hline $200 \mathrm{ml} / 2 \mathrm{~m}^{3}$ & 1.44 & 1.58 & 1.87 & 2.46 & 5.36 \\
\hline $200 \mathrm{ml} / 1.5 \mathrm{~m}^{3}$ & 1.49 & 1.64 & 1.9 & 2.7 & 5.5 \\
\hline
\end{tabular}

Table-3: Unsoaked CBR Value of Enzymatic soil.

\begin{tabular}{c|c|c|c|c|c}
\hline \multicolumn{7}{c}{ Curing Period } \\
\hline Soil Enzyme Dosage & 0 Days & 7 Days & 14 Days & 21 Days & 28 Days \\
\hline Untreated soil & \multicolumn{7}{|c|}{5.3} \\
\hline $200 \mathrm{ml} / 3 \mathrm{~m}^{3}$ & 5.45 & 6.1 & 7.09 & 7.8 & 7.92 \\
\hline $200 \mathrm{ml} / 2.5 \mathrm{~m}^{3}$ & 5.6 & 6.3 & 7.12 & 7.82 & 7.99 \\
\hline $200 \mathrm{ml} / 2 \mathrm{~m}^{3}$ & 5.82 & 6.7 & 7.3 & 7.89 & 8.1 \\
\hline $200 \mathrm{ml} / 1.5 \mathrm{~m}^{3}$ & 5.94 & 6.9 & 7.6 & 8 & 8.3 \\
\hline \multicolumn{7}{|c|}{1731}
\end{tabular}


RASĀYAN $J$. Chem.

Vol. 11 | No. 4 |1729 - 1733| October - December | 2018

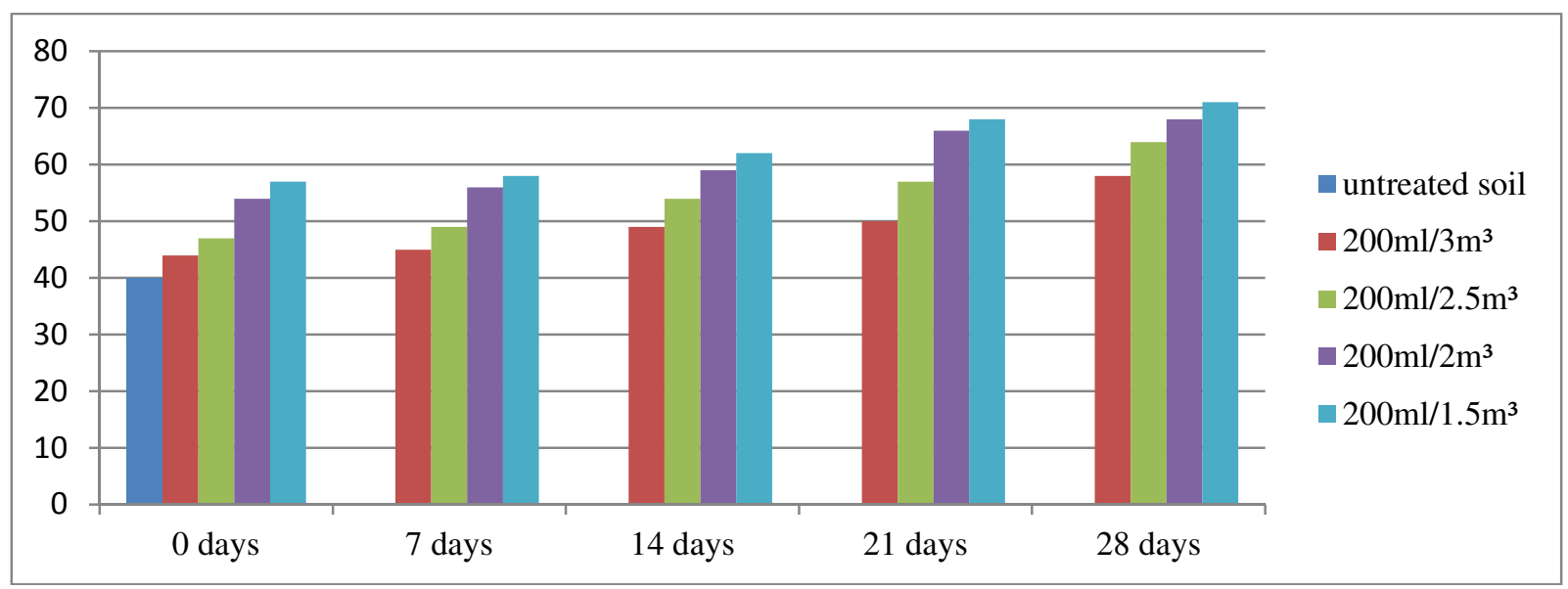

Fig.-4 :Unsoaked CBR Value of Enzymatic Soil.

Table-4: UCC Test Values of Enzymatic Soil.

\begin{tabular}{c|c|c|c|c|c}
\hline \multicolumn{7}{c}{ Curing Period } \\
\hline Soil Enzyme Dosage & 0 Days & 7 Days & 14 Days & 21 Days & 28 Days \\
\hline Untreated Soil & \multicolumn{5}{|c|}{40} \\
\hline $200 \mathrm{ml} / 3 \mathrm{~m}^{3}$ & 44 & 45 & 49 & 50 & 58 \\
\hline $200 \mathrm{ml} / 2.5 \mathrm{~m}^{3}$ & 47 & 49 & 54 & 57 & 64 \\
\hline $200 \mathrm{ml} / 2 \mathrm{~m}^{3}$ & 54 & 56 & 59 & 66 & 68 \\
\hline $200 \mathrm{ml} / 1.5 \mathrm{~m}^{3}$ & 57 & 58 & 62 & 68 & 71 \\
\hline
\end{tabular}

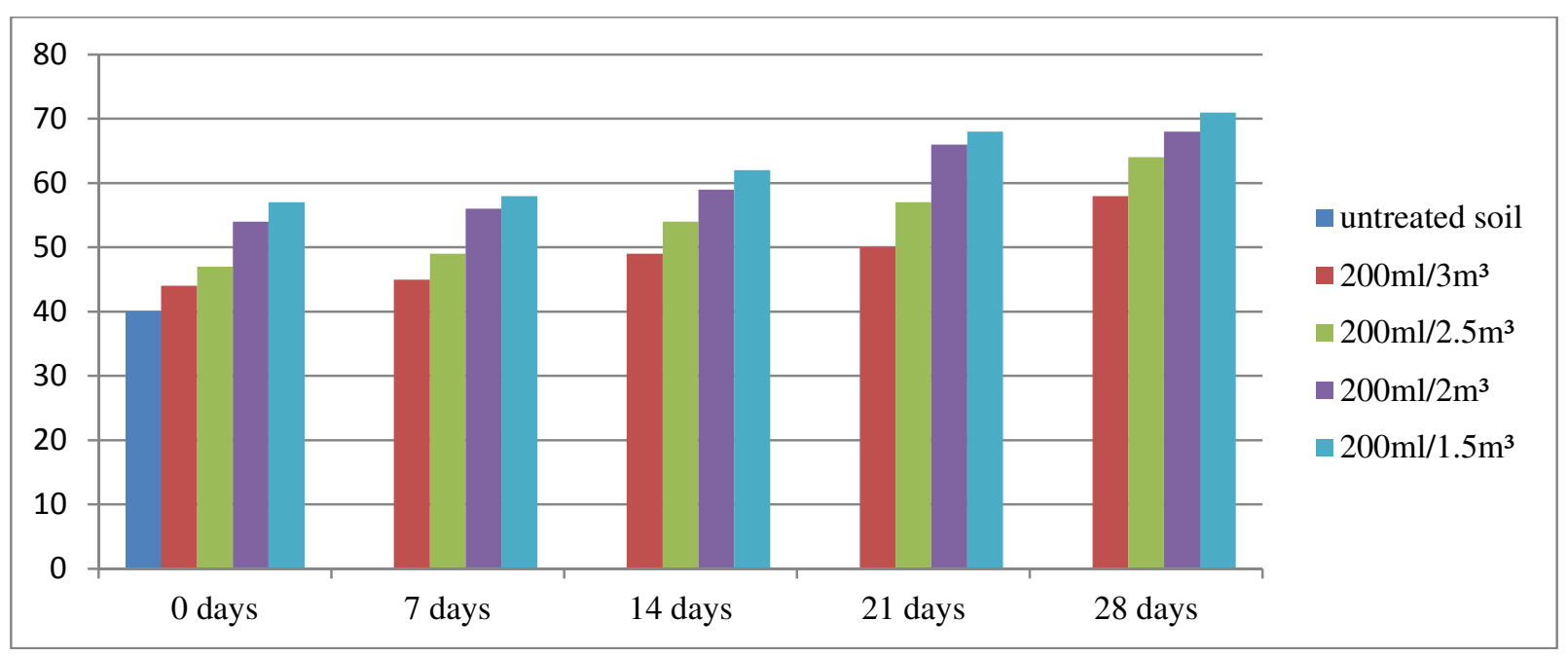

Fig.-5 : UCC Test Values of Enzymatic Soil

\section{CONCLUSION}

Unsoaked CBR value was observed with ecozyme dosage $200 \mathrm{ml}$ per $1.5 \mathrm{~m} 3$ the percentage increase for soil sample S1, S2, S3 and S4, 7.92\%, 7.99\%, 8.10\% and 8.3\% respectively. Soaked CBR value was observed with an eco-zyme dosage of $200 \mathrm{ml}$ per $1.5 \mathrm{~m} 3$ the soaked CBR value for the soil Samples S1, $\mathrm{S} 2, \mathrm{~S} 3$ and S4 was $4.9 \%, 5.15 \%, 5.36 \%$ and $5.5 \%$. The unconfined compressive strength of enzymatic soil increases with increase curing period and also the amount of enzyme. UCC values were observed with the dosage $200 \mathrm{ml} / 1.5 \mathrm{~m} 3$ of Eco-zyme at curing period of 28 days gives high strength. Higher CBR value - leads to lower total pavement thickness of the flexible pavement and this leads to saving the construction cost. Recommended that enzymatic soil (soil+eco-zyme) can be used in 
subgradeconstruction work for minimum traffic roads and village roads. The test will be done with the Curing period of minimum one year - to improve the soil strength more and more

\section{ACKNOWLEDGMENT}

This research was Fully/Partially supported by [Mr.sanmugasundaram, Assistant professor,KLNCIT,sivagangai]. We thank our colleagues from [Karunya Institute of Technology and Sciences] who provided insight and expertise that greatly assisted the research, although they may not agree with all of the interpretations/conclusions of this paper.

\section{REFERENCES}

1. Puneet Agarwal, Suneet Kaur, International Journal of Research in Engineering and Technology, 3(5), 30(2014), DOI: 10.15623/ijret.2014.0305007

2. Venika Saini, and Priyanka Vaishnava, International Journal of Advances in Engineering \& Technology, 8(4), 566(2015)

3. H.N. Ramesh, S. R. Sagar, 50th Indian Geotechnical Conference, Pune, Maharashtra, India

4. S. Gayatri Nair, International Research Journal of Engineering and Technology, 3(8) (2016)

5. Arulmurugan, Subramaniyan and Helen Kavitha and B. R., Venkatraman, Rasayan J. Chem., 3(3), 385(2010)

6. M. Kavisri, P. Senthilkumar , M. S. Gurukumar and J. Karunian, Rasayan J. Chem., 11(1), 111(2018), DOI: 10.7324/RJC.2018.1111805

7. Pranoto Pranoto1, C. Purnawan and T. Utami Rasayan J. Chem., 11(1), 23 (2018), DOI: 10.7324/RJC.2018.1111939

[RJC-3089/2018] 